\title{
Haemogregarine (Apicomplexa: Adeleorina) infection in Vanderhaege's toad-headed turtle, Mesoclemmys vanderhaegei (Chelidae), from a Brazilian Neotropical savanna region
}

\author{
Vinícius C. Goes ${ }^{1}$, Elizângela S. Brito ${ }^{2}$, Rafael M. Valadão ${ }^{3}$, Camila O. Gutierrez ${ }^{1}$, Amanda M. Picelli $^{4}$ and Lúcio \\ A. Viana ${ }^{5}$ \\ ${ }^{1}$ Laboratório de Parasitologia Animal, Centro de Ciências Biológicas e da Saúde, Universidade Federal de Mato Grosso do Sul, \\ Campo Grande, Brazil; \\ ${ }^{2}$ Programa de Pós-graduação em Ciências Veterinárias, Faculdade de Agronomia, Medicina Veterinária e Zootecnia, Universidade \\ Federal de Mato Grosso, Cuiabá, Brazil; \\ ${ }^{3}$ Instituto Chico Mendes de Conservação da Biodiversidade, Centro Nacional de Pesquisa e Conservação de Répteis e Anfíbios, \\ Goiânia, Brazil; \\ ${ }^{4}$ Programa de Pós-Graduação em Zoologia, Instituto de Ciências Biológicas, Universidade Federal do Amazonas, Manaus, Brazil; \\ ${ }^{5}$ Departamento de Ciências Biológicas e da Saúde, Universidade Federal do Amapá, Macapá, Brazil
}

\begin{abstract}
Knowledge of blood parasites in Brazilian chelonians is limited, since they have been recorded in only six species. Mesoclemmys vanderhaegei (Bour) is a freshwater turtle with a wide geographic distribution in Brazil, but there is little information about its natural history. This paper reports on a study of the prevalence and infection intensity of a haemogregarine in two subpopulations of M. vanderhaegei. The study was conducted in two areas of Cerrado in the Upper Paraguay River basin in the state of Mato Grosso, Brazil, between November 2010 and August 2013. Ninety-five (53\%) of the 179 turtles captured were positive for haemogregarine parasites. The parasitic forms observed were two morphotypes of intraerythrocytic gametocytes. The prevalence differed between size classes, increasing significantly according to the animals' body size. There was no significant difference between prevalence and sex, or between sampling periods. The mean parasite intensity was 9 parasites $/ 2,000$ erythrocytes $(0.45 \%)$ and the parasite population presented an aggregated distribution, with an aggregation index of 19 and discrepancy of 0.772 . This is the first record of a hemoparasite in the freshwater turtle M. vanderhaegei.
\end{abstract}

Keywords: prevalence, parasite intensity, hemoparasite, chelonian, Cerrado

Hemoparasites called haemogregarines (Coccidia: Adeleorina) are intracellular protists that occur in all vertebrate classes (Davies and Johnston 2000). Their life cycle is heteroxenous, and reproduction is sexual and asexual. Several groups of terrestrial and aquatic arthropods, besides leeches, serve as their vectors (Siddall and Desser 1991, Desser 1993, Davies and Smit 2001). Different genera are included in the so-called haemogregarines. Desseria Siddall, 1995, Cyrilia Lainson, 1981, Haemogregarina Danilewsky, 1885 (sensu lato) occur with fish as hosts. Hepatozoon Miller, 1908, Karyolysus Labbé, 1894, Hemolivia Petit, Landau, Baccam et Lainson, 1990, Haemogregarina (sensu stricto) have been recorded in reptiles, birds and mammals (Davies and Johnston 2000). Hemolivia and possibly Hepato- zoon terrestrial chelonians, both probably transmitted by ticks (Lainson and Naiff 1998, Paperna 2006, Harris et al. 2013). Species of Haemogregarina (sensu stricto) occur in aquatic chelonians, and are transmitted by leeches (Siddall 1995, Siddall and Desser 2001).

Records of hemoparasites exist only from six of the 36 species of turtles that occur in Brazil (Costa and Bérnils 2014). Two groups of hemoparasites have been recorded in these chelonians. The first group comprises haemogregarines of the genus Haemogregarina in Phrynops geoffroanus (Schweigger), Podocnemis unifilis Troschel, and Podocnemis expansa (Schweigger) (Campos-Brites and Rantin 2004, Soares et al. 2014, Picelli et al. 2015, Oliveira et al. 2018, Úngari et al. 2018). The second group consists

Address for correspondence: L.A. Viana, Departamento de Ciências Biológicas e da Saúde, Faculdade de Enfermagem, Universidade Federal do Amapá, 68903-419, Macapá, Brazil; Phone: +55 96 99206-9000; E-mail: lucviana74@gmail.com 


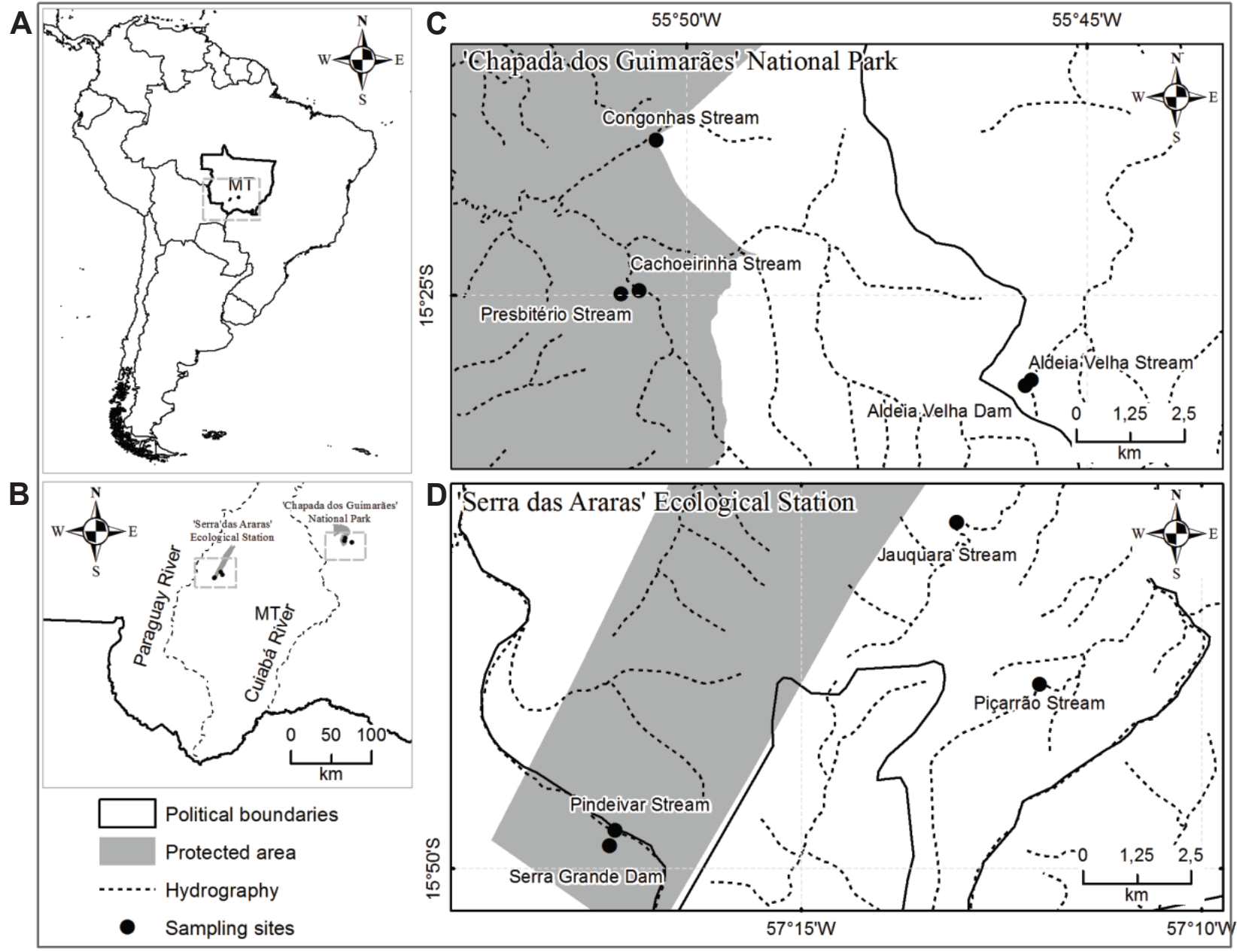

Fig. 1. Sampling sites of Mesoclemmys vanderhaegei (Bour). A, B - two protected areas of sampling sites of M. vanderhaegei; $\mathrm{C}$ - the first area is located in upland Cerrado areas in the Paraguay River basin, at the Chapada dos Guimarães National Park; $\mathrm{D}$ - the second area is located in Serra das Araras Ecological Station, in the state of Mato Grosso, Brazil.

of malarial parasites of the genus Haemoproteus Kruse, 1890, Haemoproteus peltocephali Lainson and Naiff, 1998 in Peltocephalus dumerilianus (Schweigger), Haemoproteus geochelonis (Lainson and Naiff, 1998) in Chelonoidis denticulatus (Linnaeus) and recently, Haemoproteus sp. in Chelonoidis carbonarius (Spix) (Lainson and Naiff 1998, Martinele et al. 2016).

Mesoclemmys vanderhaegei (Bour) is a medium-sized freshwater turtle with a carapace length (CL) of up to $280 \mathrm{~mm}$, weighing just over $1 \mathrm{~kg}$ (Marques et al. 2014). However, in the study area, the average CL is $157 \mathrm{~mm}$ for females and $141 \mathrm{~mm}$ for males (Brito et al. 2009).

This species occurs in various habitats, such as small streams with forest cover and highland lagoons, but it may also inhabit wetland environments containing aquatic vegetation, medium-sized rivers and reservoirs (Vinke et al. 2013, Marques et al. 2014). Distributed throughout South America, it occurs in the Amazon, São Francisco, Tocantins, Paraguay, Paraná and Uruguay river basins (Marques et al. 2014). Despite its wide geographic distribution, little is known about its natural history (Souza 2004, Marques et al. 2014) or about the occurrence of hemoparasites.
This study is part of an effort to survey and characterise hemoparasites of the phylum Apicomplexa in free-ranging turtles in Brazil. Thus, the aim of this study was to determine the prevalence and parasite intensity of a haemogregarine in two subpopulations of $M$. vanderhaegei freshwater turtles.

\section{MATERIALS AND METHODS}

The study was conducted in two conservation units located in upland Cerrado areas in the Paraguay River basin, at the Serra das Araras Ecological Station - EESA

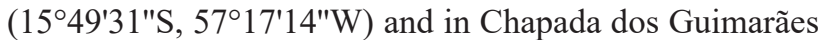
National Park - PNCG (15²4'59"S; 5550'29"W), in the state of Mato Grosso, Brazil. Specimens of $M$. vanderhaegei were captured in nine permanent streams and reservoirs in Cerrado in the Paraguay River drainage basin (Fig. 1). These water bodies are oligotrophic and have rapids, pools and waterfalls of various heights because they are located in upland areas (Fonseca 2005).

A total of 179 animals were collected between November 2010 and August 2013, 148 of which were captured at the EESA, 25 in PNCG and six from undetermined loca- 


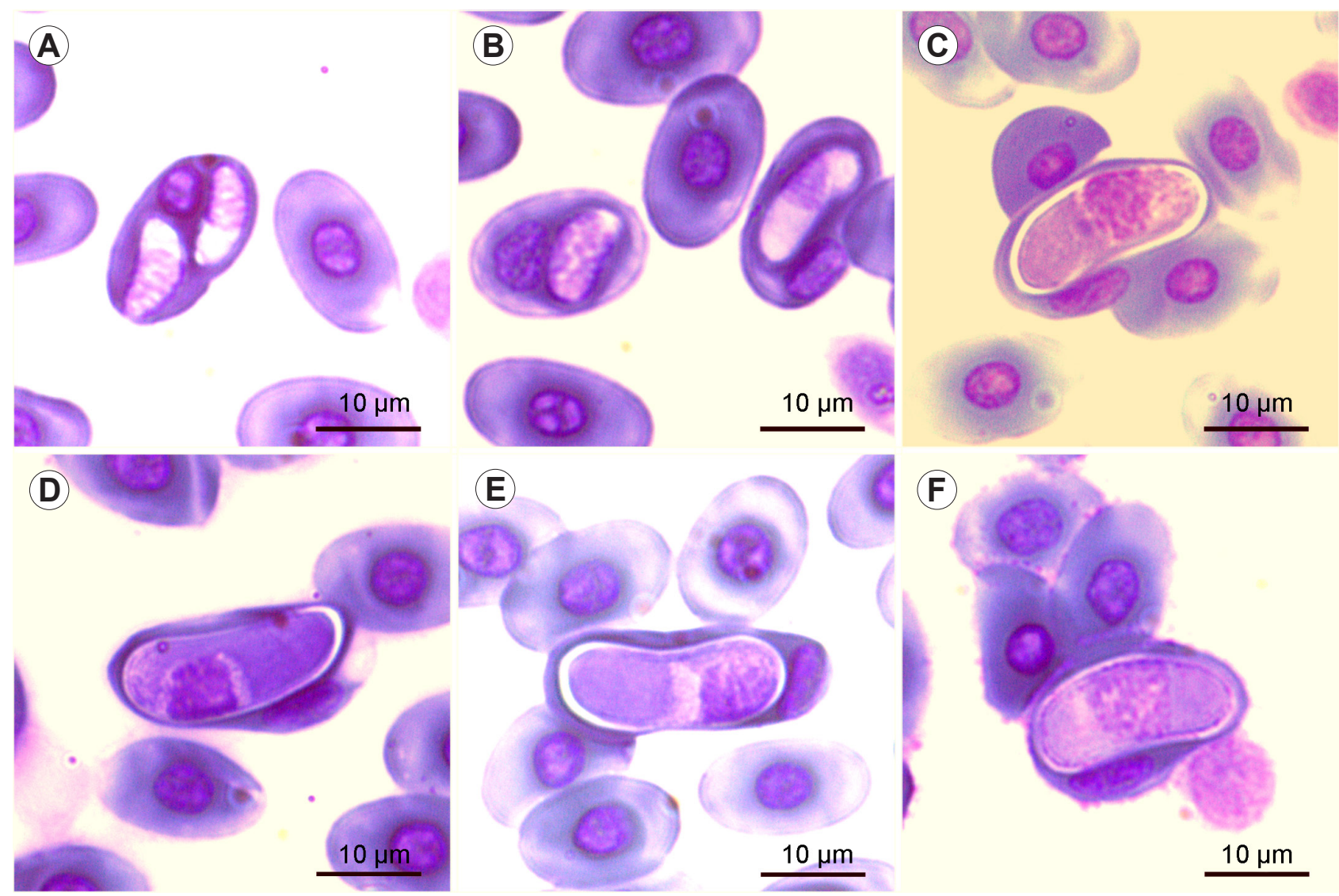

Fig. 2. Photomicrographs of haemogregarine forms from the freshwater turtle Mesoclemmys vanderhaegei (Bour) sampled in the state of Mato Grosso, Brazil; A, B - young gametocytes with the nucleus occupying about $70 \%$ of the parasite cell; $\mathbf{C}-\mathbf{F}$ - mature gametocytes with note nucleus occupying $1 / 3$ of erythrocyte.

tions. Among these animals, 50 (28\%) were recaptured at least once.

The animals were captured using funnel traps baited with beef (Brito et al. 2009), and their total length (CL) was measured. They were examined for presence of leeches and their sex was determined based on external traits, i.e. males having a comparatively longer tail than females (Brito et al. 2009).

Since we do not know the age of sexual maturity of females and males, individuals with a CL smaller than $116 \mathrm{~mm}$ were included in the category of juveniles. All captured animals were marked individually using the marking methods adapted by Cagle (1939) and Ferner (1979), which consist of a system of rectangular cuts in the marginal scutes of the carapace to identify possible recaptures.

Blood samples were collected by puncture of the vertebral venous sinus in the cervical region and turtles were released at the sites of capture. The blood smears were fixed with absolute methanol and stained with $10 \%$ Giemsa (Eisen and Schall 2000). The parasite intensity was determined based on the number of parasitic forms observed in 2,000 erythrocytes, in 20 replicates of 100 erythrocytes per field under examination (Godfrey et al. 1987). This study was authorised by the Brazilian Ministry of the Environment (Permit ICMBio - no. 25225-2).

Differences in prevalence between size classes, sex and the sampling period of the hosts were determined using the chi-square test. The prevalence in the recaptured turtles was compared using Fisher's exact test. Logistic regression analysis was used to describe changes in the probability of infection as a function the of animals' body size. The correlation of parasite intensity between the turtles' weight and size was verified using Spearman's correlation coefficient $\left(r_{s}\right)$. The Kruskal-Wallis test was used to compare the parasite intensity and sex of $M$. vanderhaegei. The distribution of the parasite in individuals was determined by the dispersion index (variance by the mean of parasite intensity) and by the discrepancy index (D). Statistical analyses were performed using BioEstat 5.0 and Quantitative Parasitology 3.0 software (Rozsa et al. 2000, Ayres et al. 2007). Values were considered statistically significant at $p<0.05$.

\section{RESULTS}

Among the 179 captured turtles, 95 (53\%) were positive for haemogregarines. The parasitic forms observed were gametocytes, both showing an elongated shape. Young gametocytes were relatively smaller, with the nucleus occupying about $70 \%$ of the parasite cell (Fig. 2A,1B), while mature forms showed relatively small nucleus at the end of the cell or centrally (Fig. 2C-F). However, no meronts were found in the blood smears.

Prevalence differed between the different size classes $\left(\chi^{2}=12.069 ; d f=3 ; p<0.007\right)$. However, juveniles with $\mathrm{CL}$ smaller than $69 \mathrm{~mm}(\mathrm{n}=6)$ presented no haemogregarine 


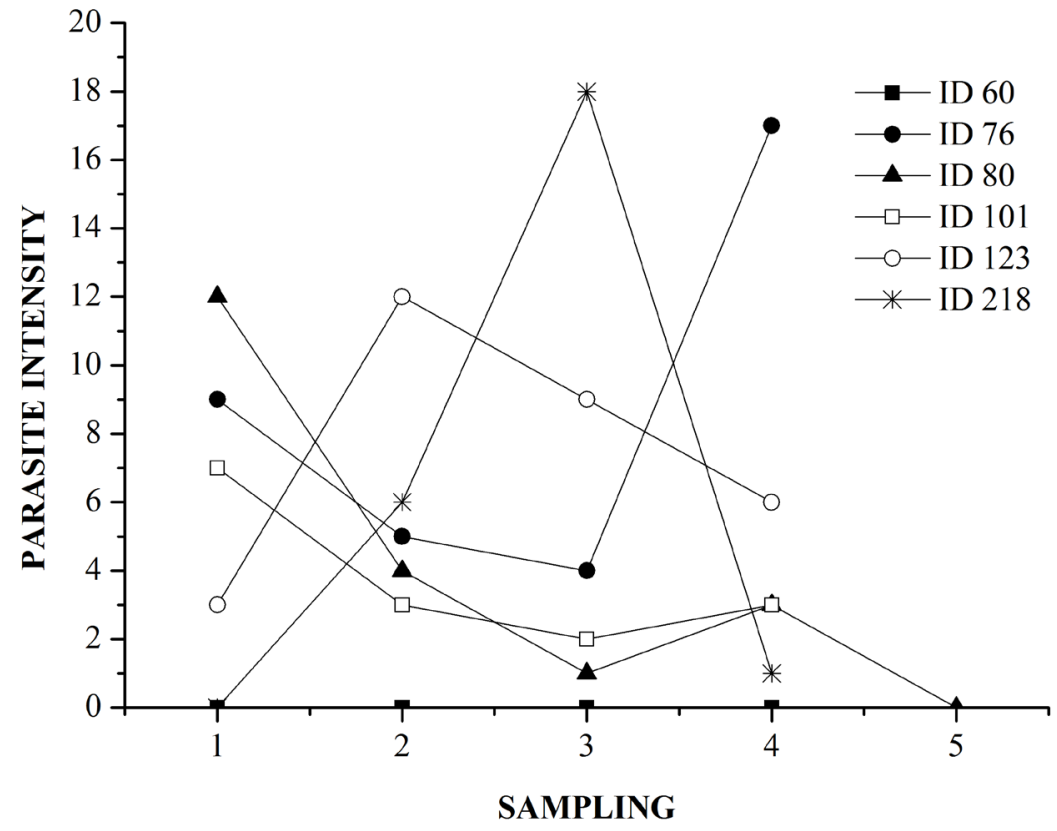

Fig. 3. Parasite intensity of haemogregarine in six Mesoclemmys vanderhaegei (Bour) recaptured at least four times. ID - Individual host identification.

infections. There was no significant difference between the prevalence and sex of the individuals $\left(\chi^{2}=0.143 ; d f=1\right.$; $p=0.705)$ and sampling periods $\left(\chi^{2}=18.081 ; d f=15\right.$; $p=0.203)$. The logistic regression analysis revealed that prevalence increases significantly according to the animal's body size $\left(\chi^{2}=5.307 ; d f=1 ; p=0.021\right)$. Leeches were relatively frequent on the captured turtles $(66 \%, \mathrm{n}=173)$.

The mean parasite intensity was 9 parasites/2,000 erythrocytes $(0.45 \%)$. No significant difference was found between the parasite intensity and sex of the hosts (Kruskal-Wallis $\mathrm{H}=1.407 ; p=0.236$ ). Parasite intensity was not significantly correlated with the turtle's body mass $\left(\mathrm{n}=91 ; r_{s}=0.035 ; p=0.742\right)$ and size $\left(\mathrm{n}=91 ; r_{s}=0.045\right.$; $p=0.671)$. The parasite population presented an aggregated distribution, with an aggregation index of 19 and (D) of 0.772 , with relatively few hosts showing high parasite intensities.

During the study, six individuals were recaptured at least four times, all from a reservoir located in the EESA. The parasite intensity levels are therefore presented in the order in which the individuals were recaptured over time (Fig. 3). The infection levels varied without a defined pattern, with two individuals (ID $218 \%$ and ID 123 \%) first presenting an increase and then a decrease in parasite intensity. In the first sampling, the individual ID 218 was negative, but in the second sampling it was found to have acquired the infection. Surprisingly, the individual ID 60 () showed no infection in any of its four samplings. Moreover, the individual ID 80 , although positive in four samplings, was the only one that became negative.

\section{DISCUSSION}

Variable levels of haemogregarine prevalence have been recorded in turtles in Brazil (Picelli et al. 2015). The prevalence recorded for Mesoclemmys vanderhaegei was relatively higher than that found in Phrynops geoffroanus (Schweigger) a chelonian of the same family $(27.6 \%$, $\mathrm{n}=58$ ), which was studied in an anthropised areas in the Cerrado (Campos-Brites and Rantin 2004). In two other studies in Brazil, haemogregarines were recorded in $66 \%$ $(\mathrm{n}=75)$ of Podocnemis expansa (Schweigger) individuals (Picelli et al. 2015) and 98\% $(\mathrm{n}=78)$ of Podocnemis unifilis Troschel individuals (Soares et al. 2014), both of which are large species distributed throughout the Amazon region.

The prevalence over time estimated by recaptures of M. vanderhaegei for approximately 3 years of sampling suggests the occurrence of an enzootic cycle of haemogregarines in the study area. Thus, it can be inferred that the infection is present in the population of $M$. vanderhaegei at any time of year. This can be explained by some factors: (i) studies have shown that hemoparasite infections in reptiles may persist for relatively long periods (Sorci 1995, Široký et al. 2004, Salkeld and Schwarzkopf 2005, Viana et al. 2010): (ii) the relatively common presence of leeches on the captured animals suggests frequent contact between the probable vector and the turtles.

With regard to size classes, a positive correlation was observed between prevalence and size of the captured animals. This pattern of infection was also observed by Sorci (1996) in the lizard Zootoca vivipara (Lichtenstein), which showed a significantly increased prevalence of haemogregarines as a function of the host's size/age. Infections in $M$. vanderhaegei were found in individuals with a $\mathrm{CL}$ starting from $69 \mathrm{~mm}$, i.e. individuals are infected in their first year of life. Individuals with a CL of $69 \mathrm{~mm}$ have an umbilical scar, indicating that they are a few months old. Therefore, we believe that the infection occurs during the first year of life. This assumption is reinforced by the fact that several individuals with a CL of $50 \mathrm{~mm}$ (hatchlings) already have leeches attached to their feet (E. S. Brito, 
pers. comm). This is probably the prepatent period until detection of gametocytes in the host's bloodstream (Siddall and Desser 1991).

The mean parasite intensity of haemogregarines in M. vanderhaegei was relatively similar to that found in the majority of turtle species (see Picelli et al. 2015). However, in comparison with two other Brazilian turtle species that have been studied, the average intensity of $M$. vanderhaegei was relatively lower. In P. unifilis in the Tapajós River in the state of Pará, the average was $6 \%(n=78)$, and in P. expansa in the Javaés River in the state of Tocantins, the average was 3\% $(\mathrm{n}=25)$ (Soares et al. 2014, Picelli et al. 2015). The factors involved in these differences are still unknown, but the type of environment occupied by these hosts is probably important. Podocnemis unifilis and $P$. expansa occur in large rivers and lakes, which are eutrophic environments, whereas $M$. vanderhaegei lives in small oligotrophic streams. Contact between leeches and turtles may be facilitated in eutrophic environments, since turtles generally shelter under submerged vegetation (Sawyer 1986), contributing to the recruitment of new infections and the resulting increase in parasite intensity in these animals.

The distribution of parasite intensity in $M$. vanderhaegei was aggregated, which is a relatively common charac- teristic in host-parasite systems (Hardin and Janovy 1988, Moritz et al. 1991, Poulin 1993). However, in the present study, the distribution of haemogregarines in the hosts cannot be explained by the variables of sex, weight or size class. Thus, it is likely that other factors such as the genetic variability of the hosts and their susceptibility to infection influence the distribution of parasites (Pacala and Dobson 1988, Quinnell et al. 1995).

This is the first record of a hemoparasite and of its prevalence and parasite intensity in $M$. vanderhaegei, and it is also the largest sample size of turtles examined for haemogregarines. We believe that new morphological and molecular studies should be conducted for a specific description of the parasite.

Acknowledgements. The authors are indebted to the staff of the Chico Mendes Institute for Biodiversity Conservation (ICMBio) at Chapada dos Guimarães National Park and of the Serra das Araras Ecological Station for their assistance during the collection of field data. We also thank the National Centre for Research and Conservation of Reptiles and Amphibians (RAN) for granting the permit to capture $M$. vanderhaegei (ICMBio - no. 25225-2). We are especially grateful to all the people who helped collect field data, and to CAPES (Brazil's Federal Agency for the Support and Improvement of Higher Education) for the postdoc grant awarded to E. S. Brito.

\section{REFERENCES}

Ayres M., Ayres Jr. M., Ayres D.L., Santos A.A. 2007: BioEstat: Aplicações Estatísticas nas Áreas das Ciências Biomédicas. Versão 5.0. Sociedade Civil Mamirauá, Belém, 324 pp.

Brito E.S., Strussmann C., Penha J.M.F. 2009: Population structure of Mesoclemmys vanderhaegei (Bour, 1973) (Testudines: Chelidae) in the Cerrado of Chapada dos Guimarães, Mato Grosso, Brazil. Biota Neotrop. 9: 245-248.

CAGLE F.R. 1939: A system of marking turtles for future identification. Copeia 3: 170-173.

CAmpos-Brites V.L., RANTin F.T. 2004: The influence of agricultural and urban contamination on leech infestation of freshwater turtles, Phrynops geoffroanus, taken from two areas of the Uberabinha River. Environ. Monit. Assess. 96: 273-281.

Costa H.C., Bérnils R.S. (Eds.) 2014: Brazilian reptiles: List of species. World Wide Web electronic publication, www.sbherpetologia.org.br, 2/2017.

Davies A.J, Johnston M.R.L. 2000: The biology of some intraerythrocytic parasites of fishes, amphibians and reptiles. Adv. Parasitol. 45: 1-107.

Davies A.J, Smit N.J. 2001: The life cycle of Haemogregarina bigemina (Adeleina: Haemogregarinidae) in South African hosts. Folia Parasitol. 48: 169-177.

Desser S.S. 1993: The Haemogregarinidae and Lankesterellidae. In: J.P. Kreier (Ed.), Parasitic Protozoa. Vol. 4. The Second Edition. Academic Press, San Diego, pp. 247-272.

Eisen R.J., Schall J.J. 2000: Life story of a malaria parasite (Plasmodium mexicanum): independent traits and basis for variation. Proc. R. Soc. Lond. B. Biol. Sci. 267: 739-799.

FERNER J.W. 1979: A review of marking techniques for amphibians and reptiles. Society for the Study of Amphibians and Reptiles, Herp. Circular 9: 1-41.

FonseCA C.P. 2005: Caracterização dos ecossistemas aquáticos do Cerrado. In: A. Scarlot, J.C. Souza-Silva, J.M. Felfili (Eds.), Cerrado: Ecologia, Biodiversidade e Conservação. Ministério do Meio Ambiente, Brasília, pp. 416-429.
Godfrey R.D.Jr., Fedynich A.M., Pence D.B. 1987: Quantification of haematozoa in blood smears. J. Wildl. Dis. 23: 558-565.

Hardin E.L., JANOvy Jr.J. 1988: Population dynamics of Distoichometra bufonis (Cestoda: Nematotaeniidae) in Bufo woodhousii. J. Parasitol. 74: 360-365.

Harris D.J., Graciá E., Jorge F., Maia J.P., Perera A., Carretero M.A., Giménez A. 2013: Molecular detection of Hemolivia (Apicomplexa: Haemogregarinidae) from ticks of North African Testudo graeca (Testudines: Testudinidae) and an estimation of their phylogenetic relationships using 18S rRNA sequences. Comp. Parasitol. 80: 292-296.

LAINSON R., NAIfF R.D. 1998: Haemoproteus (Apicomplexa: Haemoproteidae) of tortoises and turtles. Proc. R. Soc. Lond. (Biol.) 265: 941-949.

Marques T.S., Böhm S., Brito E.S., Cabrera M.R., Verdade L.M. 2014: Mesoclemmys vanderhaegei (Bour 1973) - Vanderhaege's toad-headed turtle, Karumbé-hy. In: A.G.J. Rhodin, P.C.H. Pritchard, P.P. van Dijk, R.A. Saumure, K.A. Buhlmann, J.B. Iverson and R.A. Mittermeier (Eds.), Conservation Biology of Freshwater Turtles and Tortoises: A Compilation Project of the IUCN/SSC Tortoise and Freshwater Turtle Specialist Group. Chelon. Res. Monogr. 5: 1-8.

Martinele I., Tostes R., Castro R., D’Agosto M. 2016: Prevalence of Haemoproteus spp. (Apicomplexa: Haemoproteidae) in tortoises in Brazil and its molecular phylogeny. Parasitol. Res. 115: 249-254.

Moritz C., McCallum H., Donnellan S., Roberts J.D. 1991: Parasite loads in parthenogenetic and sexual lizards (Heteronotia binoei): support for the Red Queen hypothesis. Proc. R. Soc. Lond. B. Biol. Sci. 244: 145-149.

Oliveira J.P., André M.R., Alves Júnior J.R.F., Lustosa A.P.G., Werther K. 2018: Molecular detection of hemogregarines and haemosporidians in Brazilian free-living testudines. Int. J. Parasitol. Parasites Wildl. 7: 75-84. 
PaCala S.W., Dobson A.P. 1988: The relation between the number of parasites/host and host age: population dynamic causes and maximum likelihood estimation. Parasitology 96: 197-210.

Paperna I. 2006: Hemolivia mauritanica (Haemogregarinidae: Apicomplexa) infection in the tortoise Testudo graeca in the Near East with data on sporogonous development in the tick vector Hyalomna aegyptium. Parasite 13: 267-273.

Picelli A.M., Vasconcelos A.C., Viana L.A., Malvasio A. 2015: Prevalence and parasitemia of Haemogregarina sp. in Podocnemis expansa (Testudines: Podocnemididae) from the Brazilian Amazon. Rev. Bras. Parasitol. Vet. 24: 191-197.

Poulin R. 1993: The disparity between observed and uniform distributions: a new look at parasite aggregation. Int. J. Parasitol. 23: 937-944.

Quinnell R.J, Grafen A., Woolhouse M.E.J. 1995: Changes in parasite aggregation with age: a discrete infection model. Parasitology 111: 635-644.

Rozsa L., Reiczigel J., Majoros G. 2000: Quantifying parasites in samples of hosts. J. Parasitol. 86: 228-232.

SAlKeld D.J., Schwarzkopf L. 2005: Epizootiology of blood parasites in an Australian lizard: a mark-recapture study of a natural population. Int. J. Parasitol. 35: 11-18.

SAWYer T. 1986: Leech Biology and Behaviour. Vol. 2. Feeding Biology, Ecology, and Systematics. Clarendon Press, Oxford, $374 \mathrm{pp}$.

SidDall M.E. 1995: Phylogeny of adeleid blood parasites with a partial systematic revision of the haemogregarine complex. J. Eukaryot. Microbiol. 42: 116-125.

SidDall M.E., Desser S.S. 1991: Merogonic development of Haemogregarina balli (Apicomplexa: Adeleina: Haemogregarinidae) in the leech Placobdella ornata (Glossiphoniidae), its transmission to a chelonian intermediate host and phylogenetic implications. J. Parasitol. 77: 426-436.
Siddall M.E., Desser S.S. 2001: Transmission of Haemogregarina balli from painted turtles to snapping turtles through the leech Placobdella ornata. J. Parasitol. 87: 1217-1218.

ŠIroký P., Kamler M., Modrý, D. 2004: Long-term occurrence of Hemolivia cf. mauritanica (Apicomplexa: Adeleina: Haemogregarinidae) in captive Testudo marginata (Reptilia: Testudinidae): evidence for cyclic merogony? J. Parasitol. 90: 1391-1393.

Soares P., Brito E.S., Paiva F., Pavan D., Viana L. A. 2014 Haemogregarina spp. in a wild population from Podocnemis unifilis Troschel, 1848 in the Brazilian Amazonia. Parasitol. Res. 113: 4499-4503.

SoRCi G. 1995: Repeated measurements of blood parasites levels reveal limited ability for host recovery in the common lizard (Lacerta vivipara). J. Parasitol. 81: 825-827.

SoRCI G. 1996: Patterns of haemogregarine load, aggregation and prevalence as a function of hostage in the lizard Lacerta vivipara. J. Parasitol. 82: 676-678.

SouZA F.L. 2004: Uma revisão sobre padrões de atividade, reprodução e alimentação de cágados brasileiros (Testudines, Chelidae). Phyllomedusa 3: 15-27.

Úngari L.P., Santos A.L.Q., O’Dwyer L.H., Da Silva M.R.L., de Melo Fava N.N., Paiva G.C.M., De Melo Costa Pinto R., CURY M.C. 2018: Haemogregarina podocnemis sp. nov.: description of a new species of Haemogregarina Danilewsky 1885 (Adeleina: Haemogregarinaidae) in free-living and captive yellow-spotted river turtles Podocnemis unifilis (Testudines: Podocnemididae) from Brazil. Parasitol. Res. 117: 1535-1548.

Viana L.A., Paiva F., Coutinho M.E., Lourenço-De-OliveiRA R. 2010: Hepatozoon caimani (Apicomplexa: Hepatozoidae) in wild caiman, Caiman yacare, from the Pantanal Region, Brazil. J. Parasitol. 96: 83-88.

Vinke T., Vinke S., KöHLer G. 2013: What is known about Mesoclemmys vanderhaegei (Bour 1973): a systematic review of the available literature. Paraguaria Nat. 1: 21-31.

Cite this article as: Goes V.C, Brito E.S., Valadão R.M., Gutierrez C.O., Picelli A.M. and Viana L.A. 2018: Haemogregarine (Apicomplexa: Adeleorina) infection in Vanderhaege's toad-headed turtle, Mesoclemmys vanderhaegei (Chelidae), from a Brazilian Neotropical savanna region. Folia Parasitol. 65: 012. 